\title{
KEBIJAKAN PEMBERATAN PEMIDANAAN PADA PELAKU KEKERASAN SEKSUAL TERHADAP ANAK DALAM PERSPEKTIF TUJUAN PEMIDANAAN
}

\author{
Ari Wibowo \\ Fakultas Hukum Universitas Islam Indonesia \\ Jl. Tamansiswa No. 158 Yogyakarta 55151 \\ Email: a.wibowo@uii.ac.id
}

\begin{abstract}
Abstrak
Keberadaan UU No. 23 Tahun 2002 tentang Perlindungan Anak merupakan bentuk komitmen negara dalam memberikan perlindungan terhadap anak. UU tersebut telah diubah untuk yang kedua kalinya melalui Perpu No. 1 Tahun 2016. Titik tekan dalam perubahan kedua ini adalah pemberatan pemidanaan pada pelaku kekerasan seksual terhadap anak agar memberikan efek jera dan mampu mencegah secara komprehensif terjadinya kekerasan seksual terhadap anak. Penelitian ini menggunakan bahan hukum primer dan skunder, dengan pendekatan yuridis normatif, kebijakan, dan filosofis. Hasil penelitian ini menunjukkan bahwa kebijakan pemberatan pidana pokok dalam Perpu No. 1 Tahun 2016 mencerminkan tujuan pemidanaan berupa teori gabungan yang mengompromikan antara teori relatif dengan teori retributif. Sementara kebijakan pemberatan pidana berupa kebiri kimia sebagai sanksi tindakan dalam Perpu No. 1 Tahun 2016 mencerminkan tujuan pemidanaan yang bukan sebagai pembalasan atau penjeraan, melainkan sebagai rehabilitasi.
\end{abstract}

\section{Kata kunci: Kekerasan Seksual Terhadap Anak, Teori Tujuan Pemidanaan}

\begin{abstract}
The existence of Law No. 23 of 2002 on Child Protection is part of the state's commitment to protect children. The Law has been amended for the second time through Perpu No. 1 of 2016. The emphasis in this second amendment is to aggravate the punishment of offender of sexual violence against children to provide a deterrent effect and prevent comprehensively the occurrence of sexual violence against children. This study used primary and secondary legal materials, with normative-juridical, policy, and philosophical approaches. This study concluded that punishment regulatin policy in Perpu No. 1 of 2016 reflects the purpose of punishment in the form of a combined theory that compromises between relative theory and retributive theory. While the policy of chemical chemistry regulation as a treatment reflects the purpose of punishment as rehabilitation.
\end{abstract}

Keywords: Sexual Violence Against Children, The Theory of Punishment Purposes

\section{A. PENDAHULUAN}

1. Latar Belakang

Anak memiliki peran strategis terhadap kelangsungan eksistensi bangsa dan negara di masa depan. Ia merupakan generasi yang akan meneruskan cita-cita 
perjuangan bangsa, sehingga diperlukan suatu lingkungan yang kondusif untuk tumbuh kembangnya baik secara fisik maupun mental. Seringkali dijumpai adanya penyimpangan sikap dan perilaku anak yang tidak dilepaskan dari pengaruh lingkungannya, baik keluarga maupun masyarakat di sekitarnya.

Dalam kenyataannya perhatian terhadap anak masih kurang maksimal, baik dari keluarga maupun masyarakat pada umumnya. Padahal anak merupakan pihak yang rentan terhadap pengaruh negatif dari lingkungan di sekitarnya karena emosinya masih labil dan belum sempurna akalnya dalam membedakan yang baik dan yang buruk. Selain itu, anak juga rentan menjadi korban tindak pidana karena kondisi fisiknya yang lebih lemah dibanding orang dewasa. Atas kondisi tersebut wajar kiranya jika perhatian negara bahkan dunia sangat besar terhadap perlindungan anak.

Berbagai instrumen nasional dibentuk dalam rangka memberikan perlindungan terhadap anak. Di Indonesia terdapat UU No. 44 Tahun 2008 tentang Pornografi yang mengatur adanya pemberatan pidana bagi pelaku tindak pidana pornografi yang melibatkan anak. Pemberatan tersebut berupa penambahan pidana hingga 1/3 (sepertiga) dari maksimum ancaman pidana normal. Pemberatan ini ditujukan untuk menjerakan pelaku eksploitasi dan dominasi atau pemaksaan terhadap anak-anak untuk terlibat dalam pornografi.

UU Pornografi melengkapi UU No. 23 Tahun 2002 tentang Perlindungan Anak yang sudah ada sebelumnya. UU Perlindungan Anak dibentuk dalam rangka memberikan jaminan atas perlindungan terhadap hak-hak anak agar dapat hidup, tumbuh, berkembang, dan berpartisipasi secara optimal sesuai dengan harkat dan martabat kemanusiaan, serta mendapat perlindungan dari kekerasan dan diskriminasi. Dalam rangka meningkatkan perlindungan terhadap anak, UU No. 23 Tahun 2002 kemudian diubah dengan UU No. 35 Tahun 2014. Salah satu aspek penting yang termuat dalam UU 35 Tahun 2014 adalah penegasan tentang perlunya pemberatan pemidanaan bagi pelaku tindak pidana terhadap anak untuk memberikan efek jera. Selain itu, UU 35 Tahun 2014 juga mendorong adanya langkah konkrit untuk memulihkan kembali fisik, psikis, dan sosial anak korban tindak pidana untuk mengantisipasi anak korban agar di kemudian hari tidak menjadi pelaku kejahatan seperti yang pernah dialaminya.

Belum lama diubah, UU No. 23 Tahun 2002 kembali diubah dengan Perpu No. 1 Tahun 2016. Titik tekan dalam perubahan kedua ini adalah pemberatan pemidanaan terhadap pelaku kekerasan seksual terhadap anak agar lebih memberikan efek jera dan mampu mencegah secara komprehensif terjadinya kekerasan seksual terhadap anak. Dalam Penjelasan Perpu No. 1 Tahun 2016 secara tegas dinyatakan bahwa kekerasan seksual terhadap anak merupakan kejahatan serius (serious crime) karena mengancam dan membahayakan jiwa anak, merusak kehidupan pribadi dan tumbuh kembang anak, serta mengganggu rasa kenyamanan, ketentraman, keamanan, dan ketertiban masyarakat.

Berdasarkan data Komisi Nasional Perlindungan Anak (Komnas PA), dalam 3 (tiga) tahun terakhir ini angka kekerasan terhadap anak sangat tinggi dan rata-rata setengahnya berupa kekerasan seksual. Pada 2014, 52 persen dari 4.638 kasus kekerasan terhadap anak merupakan kekerasan seksual. Tahun 2015, tercatat dari 6.726 kasus kekerasan terhadap anak, 58 persennya berupa kekerasan seksual. Adapun dari Januari sampai April 2016 terdapat 339 laporan kasus kekerasan 
terhadap anak dan 48 persennya berupa kekerasan seksual. ${ }^{1}$

Begitu masifnya kasus kekerasan seksual terhadap anak sehingga diperlukan langkah hukum yang luar biasa dalam penanggulangannya, salah satunya melalui pemberatan pemidanaan terhadap pelakunya. Secara umum Perpu No. 1 Tahun 2016 mengatur 2 (dua) pemberatan pemidanaan. Pertama, pemberatan pidana pokok dalam hal kekerasan seksual dilakukan oleh lebih dari 1 (satu) orang secara bersamasama, dilakukan oleh seseorang yang pernah dipidana karena melakukan tindak pidana kekerasan seksual, dan beberapa bentuk kekerasan seksual lainnya.

Kedua, pemberatan berupa tindakan kebiri kimia disertai pemasangan cip. Perumusan tindakan berupa kebiri kimia ini memunculkan kontroversi. Berbagai argumentasi penolakan terhadap kebiri, misalnya pidana kebiri hanya emosional dan tidak akan efektif untuk membuat jera pelakunya, ${ }^{2}$ serta melanggar Hak Asasi Manusia. ${ }^{3}$ Sementara argumentasi yang mendukung pemberlakuan kebiri karena banyak negara yang menerapkannya untuk meningkatkan efektifitas penjeraan terhadap pelaku kekerasan seksual.

Dari penjelasan di atas, pemberatan pemidanaan yang diatur dalam Perpu No. 1 Tahun 2016 perlu dikaji secara akademis berdasarkan teori tujuan pemidanaan yang dikenal dalam khazanah Ilmu Hukum Pidana. Kajian ini diperlukan karena pemberatan pemidanaan seharusnya didasarkan pada justifikasi teori tertentu, tidak bersifat responsif-emosional terhadap fenomena tindak pidana tertentu yang dianggap luar biasa untuk segera ditanggulangi.

\section{Rumusan Masalah}

a. Bagaimanakah kebijakan umum pemberatan pemidaan terhadap pelaku kekerasan seksual terhadap anak ?

b. Bagaimanakah pengaturan kebijakan kebiri terhadap pelaku kekerasan seksual terhadap anak?

\section{B. PEMBAHASAN}

\section{Kebijakan Umum Pemberatan Pemidanaan}

Perubahan yang diatur dalam Perpu No. 1 Tahun 2016 ditekankan pada pemberatan pidana kekerasan seksual terhadap anak. Penekanan ini ditegaskan dalam konsiderans huruf b Perpu No. 1 Tahun 2016 bahwa kekerasan seksual terhadap anak sudah semakin meningkat secara signifikan yang mengancam dan membahayakan jiwa anak, merusak kehidupan pribadi dan tumbuh kembang anak, serta mengganggu rasa kenyamanan, ketentraman, keamanan, dan ketertiban masyarakat. Selanjutnya dalam konsiderans huruf c dijelaskan bahwa pidana yang dijatuhkan bagi pelaku kekerasan seksual terhadap anak belum memberikan efek jera dan belum mampu mencegah secara komprehensif terjadinya kekerasan seksual terhadap anak.

Berdasarkan konsiderans Perpu sebagaimana dijelaskan di atas, terlihat bahwa pemberatan pemidanaan dalam Perpu No. 1 Tahun 2016 bertujuan memberikan efek jera kepada pelaku kekerasan terhadap anak. Kepentingan yang hendak dilindungi dari kebijakan tersebut menyangkut 2 (dua) pihak, yaitu anak dan masyarakat. Terkait dengan anak, kepentingan yang hendak dilindungi adalah jiwa anak, serta

\footnotetext{
${ }^{1}$ http://www.republika.co.id, diakses tanggal 15 Juni 2016

2 http://nasional.republika.co.id, diakses tanggal 21 Juni 2016

3 http://www.beritasatu.com, diakses tanggal 21 Juni 2016
} 
kehidupan pribadi dan tumbuh kembangnya. Sementara dalam hubungannya dengan masyarakat secara umum, kepentingan yang hendak dilindungi adalah rasa kenyamanan, ketentraman, keamanan, dan ketertiban masyarakat.

Kebijakan pemberatan pidana, khususnya pidana pokok, diatur dalam Pasal 81 ayat (1) sampai ayat (5) ditujukan dalam hal sebagai berikut: Pertama, kekerasan seksual yang dilakukan oleh orang tua, wali, orang-orang yang mempunyai hubungan keluarga, pengasuh anak, pendidik, tenaga kependidikan, atau aparat yang menangani perlindungan anak. Pemberatan ini dilatarbelangi bahwa pihak-pihak tersebut merupakan orang-orang terdekat anak sehingga potensi untuk melakukan kekerasan terhadap anak lebih besar dengan memanfaatkan kondisi fisik dan psikis anak yang lebih lemah. Beberapa tahun terakhir ini banyak kasus-kasus kekerasan seksual yang dilakukan oleh orang-orang terdekat anak, sehingga dibutuhkan proteksi yang lebih besar terhadap anak dari potensi kekerasan seksual yang dilakukan oleh orang-orang terdekatnya. Selain orang-orang terdekat anak, mereka juga memiliki kewajiban untuk memberikan perlindungan terhadap anak, baik karena ada hubungan keperdataan, hubungan kerja, maupun karena profesinya berkaitan dengan perlindungan terhadap anak. Dengan demikian, pemberatan juga dimaksudkan karena adanya unsur pengingkaran terhadap kewajiban yang melekat pada diri seseorang.

Kedua, kekerasan seksual yang dilakukan oleh lebih dari 1 (satu) orang secara bersama-sama. Pemberatan ini ditujukan dalam kasus kekerasan seksual berupa delik penyertaan (deelneming delicten), yaitu ada 2 (dua) orang atau lebih yang mengambil bagian dalam mewujudkan suatu tindak pidana. ${ }^{4}$ Karena bentuk pertanggungjawaban dalam delik ini tidak diatur secara khusus dalam Perpu No. 1 Tahun 2016, maka merujuk kepada aturan umum (lex generalis) yang diatur dalam Pasal 55 dan 56 KUHP. Sebagaimana diatur dalam kedua pasal tersebut, ada 2 (dua) pihak yang dapat dipertanggungjawabkan dalam delik penyertaan, yaitu pembuat delik dan pembantu delik. ${ }^{5}$ Pihak yang dapat dianggap sebagai pembuat delik meliputi pelaku (pleger), orang yang menyuruhlakukan (doenpleger), orang yang turut serta (medepleger), dan orang yang menganjurkan (uitlokker). Sementara pembantu delik disebut medeplichtiger.

Jika melihat rumusan Pasal 81 ayat (3) Perpu No. 1 Tahun 2016 “...dilakukan oleh lebih dari satu orang secara bersama-sama”, maka pemberatan pidana diberlakukan terhadap semua pihak yang terlibat dalam kekerasan seksual secara penyertaan baik yang berkualitas sebagai pembuat delik maupun pembantu delik. Ketentuan pemberatan pidana semacam ini tidak dikenal dalam KUHP, sehingga merupakan ketentuan khusus (lex spesialis). Meskipun Pasal 103 KUHP memperbolehkan adanya penyimpangan terhadap asas-asas yang diatur dalam Buku Kesatu KUHP, namun tetap harus memperhatikan prinsip keadilan (proporsionalitas) dalam pengaturannya. Rumusan yang mempersamakan pidana bagi pembantu delik dengan pembuat delik tentu tidak adil karena pembantu delik perannya hanya membantu pada persiapan tindak pidana atau memainkan peranan selaku bawahan,

\footnotetext{
${ }^{4}$ Erdianto Effendi, Hukum Pidana Indonesia-Suatu Pengantar, Bandung: PT Refika Aditama, 2011, hlm. 174

${ }^{5}$ Eddy O.S Hiariej, Prinsip-prinsip Hukum Pidana, Yogyakarta: Cahaya Atma Pustaka, 2014, hlm. 295
} 
sehingga perbuatannya agak bersifat skunder. ${ }^{6}$ Sifat pembantuan juga tidak sangat menentukan bagi terjadinya suatu tindak pidana. Itulah sebabnya menurut Pasal 57 ayat (1) KUHP pembantu delik diancam dengan maksimum pidana pokok dikurangi 1/3 (sepertiga). Dengan demikian, seharusnya ketentuan Pasal 81 ayat (3) Perpu No. 1 Tahun 2016 dikecualikan bagi pembantu delik.

Ketiga, kekerasan seksual yang dilakukan oleh pelaku yang pernah dipidana karena melakukan kekerasan seksual Pasal 76D. Dalam hal ini pemberatan pidana ditujukan pada pelaku delik pengulangan (recidive delicten). Dalam Hukum Pidana dikenal 3 (tiga) jenis delik pengulangan, yaitu general recidive (pengulangan umum), special recidive (pengulangan khusus), dan tussen stelsel recidive. ${ }^{7}$ General recidive merupakan perbuatan pidana yang pelakunya telah dijatuhi pidana berdasarkan putusan pengadilan yang berkekuatan hukum tetap, dan setelah selesai menjalani pemidanaan, belum melampaui 5 (lima) tahun ia melakukan kejahatan lagi berupa kejahatan apapun. Sementara, disebut special residive jika kejahatan yang dilakukan sama dengan kejahatan yang dilakukan sebelumnya. Adapun disebut tussen stelsel recidive jika kejahatan yang dilakukan tidak sama persis namun masih dalam satu kualifikasi delik yang sama dengan kejahatan sebelumnya. Dengan demikian, terlihat jelas bahwa pengulangan yang dimaksud dalam Pasal 81 ayat (4) Perpu No. 1 Tahun 2016 adalah special recidive karena kejahatan yang dilakukan harus sama dengan kejahatan sebelumnya yakni kekerasan seksual yang dirumuskan dalam Pasal 76D UU Perlindungan Anak.

Keempat, kekerasan seksual yang korbannya lebih dari 1 (satu) orang. Kelima, kekerasan seksual yang mengakibatkan luka berat, gangguan jiwa, penyakit menular, terganggu atau hilangnya fungsi reproduksi, dan/atau korban meninggal dunia. Pemberatan keempat dan kelima ini didasarkan pada keseriusan tindak pidana dengan melihat pada korbannya, baik secara kuantitas maupun kualitas. Dalam menentukan bobot pidana memang harus diperhatikan faktor-faktor yang dapat dijadikan pertimbangan memberatkan dan meringankan pidana dari delik genus (delik yang menjadi standar pengancaman pidana dalam keadaan normal), salah satunya adalah faktor akibat dari perbuatan pelaku terhadap masyarakat dan korban. ${ }^{8}$ Sebagaimana dirumuskan dalam Pasal 81 ayat (4) dan (5) Perpu No. 1 Tahun 2016, pembuat undang-undang beranggapan bahwa kekerasan seksual yang menimbulkan korban lebih dari 1 (satu) orang, berarti lebih serius. Demikian juga jika korbannya sampai mengalami luka fisik yang berat, gangguan jiwa, penyakit menular, terganggu atau hilangnya fungsi reproduksi, dan/atau korban meninggal dunia.

Jika dilihat pada ketentuan Pasal 81 Perpu No. 1 Tahun 2016, pemberatan pidana pokok pada pelaku kekerasan seksual terhadap anak dapat dibagi menjadi 2 (dua) kategori. Kategori pertama, pemberatan berupa penambahan pidana 1/3 (sepertiga) dari ancaman pidana normal sebagaimana dimaksud pada ayat (1). Dengan penambahan pidana $1 / 3$ (sepertiga), maka pidana maksimalnya menjadi

\footnotetext{
${ }^{6}$ Jan Remmelink, Hukum Pidana, Jakarta: PT Gramedia Pustaka Utama, 2003, hlm. 324 dan 327

${ }^{7}$ M. Abdul Kholiq sebagaimana dikutip dalam Mahrus Ali, Dasar-Dasar Hukum Pidana, Jakarta: Sinar Grafika, hlm. 141-142

${ }^{8}$ Mudzakkir sebagaimana dikutip dalam Teguh Prasetyo dan Abdul Halim Barakatullah, Politik Hukum Pidana: Kajian Kebijakan Kriminalisasi dan Dekriminalisasi, Yogyakarta: Pustaka Pelajar, 2005, hlm. 45
} 
pidana penjara 20 (dua puluh) tahun dan denda sekitar Rp6.700.000.000,00 (enam miliar tujuh ratus juta rupiah). Kategori kedua, pemberatan berupa pidana mati, pidana penjara seumur hidup, atau pidana penjara dalam waktu tertentu paling singkat 10 (sepuluh) tahun dan paling lama 20 (dua puluh) tahun.

Pemberatan pidana dalam Pasal 81 Perpu No. 1 Tahun 2016 menggunakan perumusan pidana dengan sistem kumulatif. Sistem perumusan kumulatif merupakan sistem perumusan pidana dengan lebih dari 2 (dua) jenis pidana untuk suatu tindak pidana. Ciri-ciri dari perumusaan ini adalah penggunaan kata "dan", misalnya penjara dan denda. ${ }^{9}$ Artinya, pidana penjara dan denda harus dijatuhkan secara bersamaan, hakim tidak boleh memilih salah satu diantara keduanya. Perumusan ini menjadi sangat kaku dan tidak memberikan peluang kepada hakim untuk memilih jenis pidana yang sesuai pada setiap kasus. Dengan demikian, dalam kasus kekerasan seksual sebagaimana diatur dalam Pasal 81, hakim terikat untuk menjatuhkan pidana penjara paling singkat 5 (lima) tahun dan paling lama 15 (lima belas) tahun dan denda paling banyak Rp5.000.000.000,00 (lima miliar rupiah), dan kalau ada pemberatan bisa melebihi ketentuan tersebut.

Perumusan pidana dengan sistem kumulatif tersebut kurang tepat karena pidana denda yang besar tidak cocok untuk semua kasus kekerasan seksual terhadap anak. Pidana denda merupakan salah satu jenis pidana finansial yang cocok diterapkan terhadap pelaku kejahatan ekonomi dengan ciri pokoknya memiliki motif mencari keuntungan finansial sehingga dalam melakukan kejahatan selalu memperhitungkan biaya dan keuntungan (cost and benefit). ${ }^{10}$ Menurut teori penagkalan (detterence), pidana yang diancamkan terhadap pelaku kejahatan harus melebihi keuntungan yang diharapkan dari kejahatan tersebut sehingga dapat berfungsi secara efektif sebagai penangkal. Oleh karena itu harus dihindari penghukuman yang biaya marjinalnya sama dengan manfaat marjinal yang diharapkan atau dihasilkan dari suatu kejahatan.

Selain efektivitas, teori penangkalan biasanya menilai aspek efisiensi dari hukuman atas kontribusinya baik sebagai pencegahan umum (general prevention) yang mengacu pada efek hukuman untuk mempengaruhi perilaku masyarakat secara umum, maupun untuk pencegahan khusus (special prevention) yang mengacu pada dampak dari hukuman terhadap perilaku pelaku sendiri. ${ }^{11}$ Dengan demikian, untuk kekerasan seksual yang motifnya bukan finansial, pidana denda tidak efektif karena pelakunya akan cenderung memilih pidana pengganti berupa kurungan dalam waktu tertentu paling lama 6 (enam) bulan atau kalau ada pemberatan bisa sampai 8 (delapan) bulan seperti yang diatur dalam Pasal 30 KUHP. Sebaiknya delik dirumuskan menggunakan sistem kumulatif-alternatif agar hakim dapat memilih jenis pidana yang sesuai secara kasus per kasus.

Pemberatan lain yang juga terdapat dalam Pasal 81 Perpu No. 1 Tahun 2016 adalah penggunaan ketentuan pola pengancaman pidana minimum khusus (straf minima), yaitu pidana penjara minimal 5 (lima) tahun, atau kalau ada pemberatan tertentu minimal 10 (sepuluh) tahun. Penggunaan pola pengancaman pidana

${ }^{9}$ Lilik Mulyadi, Kapita Selekta Hukum Pidana, Kriminologi, dan Viktimologi, Jakarta: Djambatan, 2007, hlm. 24

${ }^{10}$ Munir Fuady, Anatomi Kejahatan Kerah Putih, Bandung: PT. Citra Aditya Bakti, 2004, hlm. 1-11

${ }^{11}$ Dan M Kahan, “The Secret Ambition Of Deterrence”, Harvard Law Review, 1999 
minimum khusus bertujuan untuk memperkuat efek penjeraan terhadap pelaku tindak pidana dan menghindari disparitas (disparity of sentencing) putusan pengadilan terhadap suatu tindak pidana. Penerapan pola pengancaman pidana minimum khusus dalam Perpu No. 1 Tahun 2016 menunjukkan bahwa kekerasan seksual terhadap anak dianggap sebagai kejahatan yang berat (serious crime), sehingga perlu ditanggulangi dengan tegas agar jangan sampai pelakunya dipidana terlalu ringan.

Dari penjelasan di atas, baik dari konsiderans maupun jenis-jenis pemberatan pidana pokoknya, Perpu No. 1 Tahun 2016 terlihat menggunakan teori tujuan pemidanaan berupa teori relatif yang bertumpu pada tujuan yang hendak dicapai dalam penjatuhan pidana, yaitu agar menimbulkan efek pencegahan sehingga tidak terjadi kejahatan serupa di masa yang akan datang baik terhadap pelakunya sendiri (special prevention) maupun masyarakat luas (general prevention). Tujuan ini sebenarnya tidak tepat jika dikaitkan dengan pidana penjara karena di Indonesia telah dilakukan perubahan konsep pemenjaraan menjadi pemasyarakatan sejak tahun 1963 yang menunjukkan bahwa telah terjadi perubahan orientasi pemidanaan dari yang semula sebagai penjeraan menjadi pembinaan sebagai upaya perbaikan narapidana. Sebagai konsekuensinya, istilah Rumah Penjara yang dulu digunakan di Indonesia diganti dengan Lembaga Pemasyarakatan (LAPAS). Dalam Pasal 1 angka 3 UU No. 12 Tahun 1995 tentang Pemasyarakatan disebutkan bahwa Lembaga Pemasyarakatan yang selanjutnya disebut LAPAS adalah tempat untuk melaksanakan pembinaan Narapidana dan Anak Didik Pemasyarakatan.

Dengan penggunaan konsep pemasyarakat tersebut, seharusnya orientasi pemenjaraan bukan untuk menimbulkan efek penjeraan melainkan sebagai prevensi khusus yang bertujuan memperbaiki pelaku agar kembali hidup normal dalam masyarakat. Dengan demikian, ancaman pidana penjara selama apapun dan dirumuskan dengan pola pengancaman pidana minimum khusus, konsepnya tetap bukan sebagai alat penjeraan melainkan sebagai pembinaan untuk memasyarakatkan kembali narapidana.

Meskipun mrnggunakan teori relatif, Perpu No. 1 Tahun 2016 tidak berarti meninggalkan sama sekali teori retributif (pembalasan). Penerapan pidana mati untuk kejahatan seksual tertentu, khususnya yang menimbulkan korban lebih dari 1 (satu) orang, mengakibatkan luka berat, gangguan jiwa, penyakit menular, terganggu atau hilangnya fungsi reproduksi, dan/atau korban meninggal dunia, pelakunya masih memungkinkan untuk dijatuhi pidana mati. Hal ini menunjukkan digunakannya teori retributif meskipun di dalamnya juga mengandung tujuan prevensi umum karena pidana mati bukan hanya sebagai suatu pembalasan namun juga di dalamnya ada tujuan untuk memberikan penjeraan kepada masyarakat agar tidak melakukan tindakan serupa.

\section{Kebijakan Pengaturan Kebiri Terhadap Pelaku Kekerasan Seksual}

Pengebirian bagi pelaku kekerasan seksual bukan merupakan jenis sanksi baru dalam hukum pidana, namun sepanjang sejarah sudah banyak dipraktikkan oleh negara-negara di dunia, dan masih banyak digunakan sampai akhir Perang Dunia Kedua. Saat itu bentuknya berupa kebiri melalui bedah (surgical castration). Kebiri sudah dijadikan pidana di Mesir kuno untuk pelaku perzinahan, kemudian diterapkan di Eropa Barat pada abad ke-12 untuk pelaku pemerkosaan, dan diterapkan di 
Perancis pada abad ke-13 untuk pelaku homoseksual. ${ }^{12}$

Karena prosedurnya yang dianggap rumit, maka banyak Negara-negara yang tidak lagi menerapkan kebiri. Baru pada 1970-an, mulai dikembangkan obat yang dapat mengurangi jumlah hormon testosteron pada pria atau yang kemudian dikenal dengan kebiri kimia (chemical castration). Swedia, Jerman, dan Denmark merupakan Negara yang pertama kali menggunakan kebiri kimia sebagai alternatif kebiri bedah, namun bukan sebagai bentuk pidana melainkan pengobatan sukarela. ${ }^{13}$

Di beberapa negara, kebiri kimia telah diterapkan untuk kekerasan seksual khususnya di Amerika Serikat dan Eropa. California merupakan negara bagian Amerika Serikat yang pertama kali menerapkan kebiri kimia. Kebiri dijadikan sebagai cara baru untuk menaggulangi pengulangan tindak pidana kekerasan seksual yang saat itu sering terjadi. Cara yang dilakukan adalah dengan menyuntikkan cairan kimia setiap minggu untuk mengurangi hormon testosteron. ${ }^{14}$ Perancis pada tahun 2005 dan Inggris pada tahun 2007 telah memperkenalkan undang-undang kebiri kimia. Di kedua negara tersebut kebiri kimia bukan kewajiban namun bersifat sukarela. $^{15}$

Indonesia sendiri baru mengakomodasi kebiri dalam hukum pidana melalui Perpu No. 1 Tahun 2016. Dalam konsiderans Perpu No. 1 Tahun 2016 terlihat bahwa jenis sanksi ini diterapkan sebagai respons atas maraknya kasus kekerasan seksual terhadap anak di Indonesia khususnya yang terjadi dalam beberapa tahun terakhir ini. Ancaman pidana penjara yang tinggi ternyata belum membuat berkurangnya minat seseorang untuk tidak melakukan kekerasan seksual terhadap anak, bahkan menurut beberapa data termasuk dari Komnas PA dalam 5 (lima) tahun terakhir cenderung meningkat.

Untuk melihat efektifitas dari suatu sanksi dalam hukum pidana, beberapa masukan yang bisa dijadikan pedoman antara lain: ${ }^{16}$

1. Masukan berbagai pertemuan ilmiah.

2. Masukan dari beberapa hasil penelitian.

3. Masukan dari pengkajian dalam pertemuan/ kongres internasional.

4. Masukan dari konvensi internasional.

5. Masukan dari pengkajian perbandingan berbagai hukum pidana asing.

Terkait dengan efektifitas kebiri dalam mengurangi kekerasan seksual, pernah dilakukan penelitian di Eropa dengan memperbandingkan sebelum dan setelah implementasi kebiri. Sebagai contoh, pada periode antara 1934 dan 1944, di Jerman sebanyak 1.036 pelaku kekerasan seksual dikebiri. Hasil penelitian yang dilakukan

${ }^{12}$ Voislav Stojanovski, "Surgical Castration of Sex Offenders and its Legality: The Case of the Czech Republic", PrF D-TPV4 Theoretical Legal Sciences, Czech Republic: Doctoral Degree Program, Department of Criminal Law VI, Universitas Masarykiana Brunensis, hlm. 4

${ }^{13}$ Debra Wilson, "The Legal Implications of Chemical Castration of Sex Offenders in Criminal Law", Paper presented at 62nd Annual Australasian Law Teachers Association (ALTA) Conference on Law and Public Policy: Taming the Unruly Horse? Perth: University of Western Australia, 23rd 26th September 2007, hlm. 2

${ }^{14}$ Lisa Keesling, "Practicing Medicine Without a License: Legislative Attempts to Mandate Chemical Castration For Repeat Sex Offenders", The John Marshall Law Review, 1999, hlm. 382

${ }^{15}$ Ibid., hlm. 3

16 M. Sholehuddin sebagaimana dikutip dalam Prasetyo dan Abdul Halim Barakatullah, Op.Cit., hlm. 46 
oleh Langelüddecke menunjukkan hanya 2,3 persen pelaku yang dikebiri kemudian menjadi residivis. Sementara sebelum diberlakukan kebiri, tingkat residivisme pelaku kekerasan seksual mencapai 39,1 persen. Hal serupa pernah diteliti di Swis oleh Cornu. Dari 127 pelaku kekerasan seksual yang diteliti, kelompok yang dikebiri memiliki tingkat residivisme 7,44 persen, dan yang tidak dikebiri memiliki tingkat residivisme 78,86 persen. ${ }^{17}$ Penelitian yang dilakukan di beberapa negara lain juga menunjukkan hasil serupa.

Dari sejumlah penelitian yang dilakukan di Eropa dan Amerika Serikat, disimpulkan bahwa tingkat pengulangan kekerasan seksual setelah pengebirian sangat rendah, yaitu hanya berkisar antara 0 dan 10 persen. Teori yang mendasari penelitian ini adalah bahwa penghapusan hormon testosteron (kebiri kimia) menyebabkan penurunan yang signifikan terhadap penyimpangan seksual, sehingga dapat meminimalisir kekerasan seksual di masyarakat. ${ }^{18}$ Hasil penelitian ini dapat digunakan oleh Indonesia dalam pemberlakuan kebiri kimia pada pelaku kekerasan seksual terhadap anak.

Pengaturan kebiri terdapat di Pasal 81 ayat (7) Perpu No. 1 Tahun 2016 yang diberlakukan tidak untuk semua kekerasan seksual, namun untuk kekerasan seksual dengan kategori tertentu, yaitu: Pertama, kekerasan seksual yang pelakunya pernah dipidana karena melakukan kekerasan seksual (recidive delicten). Kedua, kekerasan seksual yang menimbulkan korban lebih dari 1 (satu) orang, mengakibatkan luka berat, gangguan jiwa, penyakit menular, terganggu atau hilangnya fungsi reproduksi, dan/atau korban meninggal dunia.

Ketentuan semacam ini sebelumnya telah diterapkan di beberapa negara, meskipun tidak sama persis. Sebagai contoh, California menerapkan kebiri kimia hanya untuk pelaku kekerasan seksual terhadap anak yang sudah menjadi residivis saja. Kebiri kimia terhadap residivis dijadikan sebagai syarat pemberian pembebasan bersyarat. Jangka waktu penyuntikan kebiri tidak dibatasi oleh undang-undang dan bisa terus diberikan apabila negara menganggap perlu. Di Montana juga diterapkan untuk residivis namun dapat pula diterapkan untuk pelaku pertama apabila kejahatan seksual yang dilakukan dinilai sangat keji. ${ }^{19}$

Makedonia memberlakukan kebiri kimia untuk semua pelaku kekerasan seksual terhadap anak namun bersifat sukarela dan sifatnya dapat mengurangi pidana penjara, sedangkan untuk residivis kebiri kimia bersifat wajib. ${ }^{20}$ Di Polandia dan Republik Moldova, kebiri kimia diwajibkan terhadap pelaku kekerasan seksual terhadap anak di bawah usia 15 tahun. Saat ini sebagian besar negara menggunakan cara kebiri kimia, termasuk Indonesia sebagaimana ditentukan dalam Pasal 81 ayat (7) Perpu No. 1 Tahun 2016. Meskipun demikian, masih ada negara di Eropa yang masih menggunakan cara kebiri bedah, misalnya Jerman. Menurut KUHP Jerman, dalam rangka pengebirian bedah, beberapa persyaratan harus dipenuhi terlebih

\footnotetext{
${ }^{17}$ Voislav Stojanovski, Loc.Cit.
}

${ }^{18}$ Weinberger, Linda E, et.al, (2005). "The Impact of Surgical Castration on Sexual Recidivism Risk Among Sexually Violent Predatory Offenders", The Journal of the American Academy of Psychiatry and the Law, Volume 33, Number 1, 2005

${ }^{19}$ Lisa Keesling, Op.Cit., hlm. 383

20 Aleksandra Deanoska Trendafilova and Andrej Bozhinovski, "Chemical Castration -The New Security Measure in the Macedonian Criminal Legislation", International Journal of Research in Applied, Natural and Social Sciences (IMPACT: IJRANSS), Vol. 3, Issue 10, Oct 2015, hlm. 43 
dahulu, seperti persetujuan tertulis dari pelaku yang akan dikebiri, rekomendasi tertulis dari tim medis, batas usia pelaku harus di atas 25 tahun, dan tidak menyebabkan gangguan kesehatan fisik atau mental. Potugal memberlakukan kebiri kimia secara sukarela yang disertai dengan rehabiltasi fisik dan mental. ${ }^{21}$

Perpu No. 1 Tahun 2016 menentukan bahwa kebiri bukan sebagai pidana (straf/punishment) tetapi sebagai tindakan (maatregel/treatment). Dengan demikian, Perpu No. 1 Tahun 2016 menggunakan double track system, yaitu cara memperlakukan penjahat dengan cara "pidana" dan "tindakan" yang diposisikan dalam kedudukan seimbang. Di Amerika pernah terjadi perdebatan akademis apakah kebiri kimia lebih tepat dijadikan sebagai tindakan atau pidana. Ada yang berpendapat lebih tepat dijadikan sebagai tindakan, bukan pidana, dengan syarat: ${ }^{22}$.

1. Harus ada aspek terapeutik;

2. Harus diakui dan diterima dalam praktik medis;

3. Harus menjadi bagian dari program psikoterapi berkelanjutan; dan

4. Jangan sampai ada efek samping yang berat.

Sementara sebagian yang lain beranggapan lebih tepat dijadikan sebagai pidana karena kekejian perbuatan yang dilakukan pelaku. ${ }^{23}$ Penentuan kebiri kimia sebagai tindakan atau pidana tentu memiliki konsekuensi yang berbeda. Jika diposisikan sebagai pidana, maka kebiri kimia merupakan bentuk penderitaan sekaligus sebagai pernyataan pencelaan bagi pelaku. Hal ini sebagaimana dijelaskan oleh Alf Ross bahwa konsepsi pidana bertolak dari 2 (dua) syarat atau tujuan, yaitu pidana ditujukan pada pengenaan penderitaan terhadap orang yang bersangkutan, dan pidana merupakan suatu pernyataan pencelaan terhadap perbuatan pelaku. ${ }^{24}$

Kedua syarat yang dikemukakan oleh Alf Ross tersebut dimaksudkan untuk membedakan antara pidana dengan tindakan. Menurutnya, tidak dapat dipandang sebagai pidana hal-hal sebagai berikut:

1. Tindakan-tindakan yang bertujuan mengenakan penderitaan tetapi tidak merupakan pernyataan pencelaan, misalnya pemberian "electric shock" pada binatang dalam suatu penelitian agar tingkah lakunya dapat diamati atau dikontrol.

2. Tindakan-tindakan yang merupakan pernyataan pencelaan tetapi tidak dimaksudkan untuk mengenakan penderitaan, misalnya teguran, peringatan atau penyingkiran oleh masyarakat.

3. Tindakan-tindakan yang di samping tidak dimaksudkan untuk mengenakan penderitaan, juga tidak merupakan pernyataan pencelaan, misalnya tindakan dokter gigi yang mencabut gigi pasien.

Jika dipotret menggunakan teori pemidanaan, sesungguhnya ada perbedaan filosofis antara menjadikan kebiri sebagai pidana dengan tindakan. Jika sebagai pidana, berarti kebiri diposisikan sebagai pembalasan atas kekerasan seksual terhadap anak. Jenis tindak pidana yang terkait dengan seks, ancamannya adalah

\footnotetext{
${ }^{21}$ Ibid., hlm. 46

${ }^{22}$ Debra Wilson, Op.Cit., hlm. 11

23 Ibid.

${ }^{24}$ Muladi dan Barda Nawawi Arief, Teori-Teori dan Kebijakan Pidana, Bandung: PT. Alumni, hlm. 46
} 
pidana yang bersifat seksual pula sebagai pembalasan yang dianggap setimpal. Hal ini mencerminkan prinsip proporsionalitas atau keadilan retributif. Di sisi lain, kebiri juga diharapkan dapat menjadi alat pencegah kekerasan seksual terhadap anak, baik berupa efek penjeraan terhadap diri pelaku (prevensi khusus), maupun masyarakat umum agar tidak melakukan tindakan serupa (prevensi umum).

Karena Indonesia menentukan kibiri sebagai tindakan, maka kebiri tidak ditujukan sebagai pembalasan atau penjeraan, melainkan sebagai rehabilitasi atau pemulihan kondisi pelaku kejahatan agar tidak lagi melakukan kejahatan serupa di masa yang akan datang. Tujuan rehabilitasi merupakan bagian dari teori relatif yang mengajarkan bahwa sanksi dalam hukum pidana dapat dibenarkan jika semata-mata dapat memberikan manfaat bagi hak warga Negara. Sanksi dalam hukum pidana yang sifatnya menderitakan pelakunya dapat dibenarkan sejauh diperlukan untuk mencegah penderitaan atau kerugian yang lebih besar. Hanya saja, perlu juga ditekankan perumusan sanksi yang juga ditujukan untuk memberikan kesempatan kepada pelaku untuk menyadari dan merubah perilakunya. Disinilah sanksi berfungsi sebagai rehabilitasi. ${ }^{25}$ Tujuan semacam ini seringkali juga disebut utilitarian karena merupakan turunan dari filsafat moral politik utilitarian atau consequentialist yang memberikan justifikasi terhadap pemidanaan untuk tujuan mengantisipasi konsekuensi-konsekuensi yang akan ditimbulkan di masa yang akan datang. Teori ini juga sering kali disebut reductivist karena tujuan pemidanaan juga dianggap untuk mengurangi kejahatan. ${ }^{26}$

Berdasarkan proses eksistensi reform (pembinaan) dari suatu pemidanaan, tujuan pembinaan dapat dibedakan menjadi 2 (dua). Proses pertama, pembinaan lahir dari kesakitan atau penderitaan sebagai akibat dari pemidanaan itu sendiri. Sedangkan proses kedua, pembinaan lahir bersamaan dengan adanya pidana itu sendiri. Proses kedua ini sejalan dengan perkembangan perubahan pemikiran masyarakat yang lebih mempersoalkan dan memperhatikan masalah bagaimana mencegah eksistensi penjahat dibandingkan dengan masalah kejahatan. ${ }^{27}$ Sebagai proses rehabilitasi, Perpu No. 1 Tahun 2016 menentukan bahwa kebiri harus dibarengi dengan pemasangan alat pendeteksi elektronik (cip) di bawah pengawasan secara berkala oleh kementerian yang menyelenggarakan urusan pemerintahan di bidang hukum, sosial, dan kesehatan. Rehabilitasi ini penting karena banyak pelaku kekerasan seksual terhadap anak yang menderita kelainan seksual. Selain itu, anak yang pernah menjadi korban kekerasan seksual memiliki kecenderungan untuk menjadi pelaku. Sebagai contoh, Emon, terpidana kasus sodomi terhadap 39 anak yang mengaku pernah menjadi korban kekerasan seksual saat masih anak-anak.

Hal penting yang perlu diatur lebih lanjut melalui peraturan pelaksana Perpu No. 1 Tahun 2016 adalah jenis cairan kimia yang akan digunakan untuk melakukan kebiri. Cairan tersebut hendaknya dipilih jenis yang aman dan tidak menimbulkan efek samping berbahaya karena terkadang efek samping cairan kebiri kimia bisa menjadi kriminogen. Sebagai contoh, California menggunakan injeksi cairan kimia berupa Depo-Provera dalam melakukan kebiri terhadap penjahat seksual. Dalam 7

\footnotetext{
25 Andrea Ata Ujan, Filsafat Hukum: Membangun Hukum, Membela Keadilan, Yogyakarta: Kanisius, 2009, hlm. 11

${ }^{26}$ Barbara A. Hudson, Understanding Justice: An Introduction to Ideas, Perspectives and Controversies in Modern Penal Theory, Philadelphia: Open University Press, 1996, hlm. 5.

${ }^{27}$ Ibid., hlm. 85
} 
(tujuh) sampai 10 hari setelah injeksi dihentikan, produksi testosteron akan kembali meningkat yang berakibat meningkatnya kembali dorongan dan fantasi seks. Dengan demikian, Depo-Provera saja tidak akan efektif untuk mengobati pelaku seks, namun harus dikombinasikan dengan psikoterapi. ${ }^{28}$

Tidak ada studi yang dapat menjelaskan bahwa Depo-Provera cocok digunakan untuk semua jenis pelaku seks, misalnya paraphiliacs. Paraphiliacs adalah salah satu jenis pelaku seks yang didorong oleh keharusan untuk mewujudkan fantasi seksual tertentu. Karena banyak hal yang dapat mempengaruhi perilaku seksualnya, diagnosis terhadap paraphiliacs harus dilakukan secara konprehensif, yaitu meliputi kondisi afektif, kognitif, dan psikomotoriknya. ${ }^{29}$ Penggunaan Depo-Provera justru dapat menimbulkan efek samping berupa bertambahnya berat badan, berganti panas dan dingin pada badan secara sekejap, mimpi buruk, kelelahan, kram kaki, mual, sakit kepala, dan depresi. Depo-Provera dapat juga memperburuk epilepsi, asma, disfungsi jantung dan disfungsi ginjal. ${ }^{30}$

\section{SIMPULAN}

Berdasarkan pembahasan pada bab sebelumnya, dapat diperoleh kesimpulan sebagai berikut: Pertama, kebijakan pemberatan pidana pokok dalam Perpu No. 1 Tahun 2016 mencerminkan tujuan pemidanaan berupa teori gabungan yang mengompromikan teori relatif dengan teori retributif. Penggunaan teori relatif terlihat dari pemberatan pidana penjara untuk jenis kekerasan seksual tertentu, seperti penyertaan, pengulangan, dan dilakukan oleh orang-orang dekat korban, agar pembinaan terhadap pelaku di Lembaga Pemasyarakatan lebih panjang sehingga lebih siap untuk dire-sosialisasi. Sementara penggunaan teori retributif terlihat dari diakomodasinya pidana mati sebagai pemberatan pidana terhadap pelaku kekerasan seksual yang menimbulkan dampak serius terhadap korban.

Kedua, kebijakan pemberatan pidana berupa kebiri kimia sebagai sanksi tindakan dalam Perpu No. 1 Tahun 2016 mencerminkan tujuan pemidanaan yang bukan sebagai pembalasan atau penjeraan, melainkan sebagai rehabilitasi atau pemulihan kondisi pelaku kejahatan agar tidak lagi melakukan kejahatan serupa di masa yang akan datang. Tujuan rehabilitasi merupakan bagian dari teori relatif yang mengajarkan bahwa sanksi dalam hukum pidana dapat dibenarkan jika semata-mata dapat memberikan manfaat bagi hak warga Negara, sehingga penekanannya untuk memberikan kesempatan kepada pelaku untuk menyadari dan merubah perilakunya. Sebagai proses rehabilitasi, Perpu No. 1 Tahun 2016 menentukan bahwa kebiri harus diberangi dengan pemasangan alat pendeteksi elektronik (cip) di bawah pengawasan secara berkala oleh kementerian yang menyelenggarakan urusan pemerintahan di bidang hukum, sosial, dan kesehatan. Rehabilitasi ini penting karena banyak pelaku kekerasan seksual terhadap anak yang menderita kelainan seksual.

\footnotetext{
${ }^{28}$ Lisa Keesling, Op.Cit., hlm. 385

${ }^{29}$ Ibid., hlm. 386

${ }^{30}$ Ibid., hlm. 388
} 


\section{Daftar Pustaka}

Buku:

Ali, Mahrus. 2011. Dasar-Dasar Hukum Pidana. Jakarta: Sinar Grafika

Amiruddin dan Zainal Asikin. 2006. Pengantar Metodologi Penelitian Hukum.Jakarta: Rajawali Pers

Effendi, Erdianto. 2011. Hukum Pidana Indonesia-Suatu Pengantar. Bandung: PT Refika Aditama

Fuady, Munir. 2004. Anatomi Kejahatan Kerah Putih. Bandung: Citra Aditya Bakti

Hiariej, Eddy O.S. 2014. Prinsip-prinsip Hukum Pidana. Yogyakarta: Cahaya Atma Pustaka.

Hudson, Barbara A. 1996. Understanding Justice: An Introduction to Ideas, Perspectives and Controversies in Modern Penal Theory. Philadelphia: Open University Press

Muladi dan Barda Nawawi Arief. 2005. Teori-Teori dan Kebijakan Pidana. Bandung: PT Alumni

Mulyadi, Lilik. 2007. Kapita Selekta Hukum Pidana, Kriminologi, dan Viktimologi. Jakarta: Penerbit Djambatan

Prasetyo, dan Abdul Halim Barakatullah. 2005. Politik Hukum Pidana: Kajian Kebijakan Kriminalisasi dan Dekriminalisasi. Yogyakarta: Pustaka Pelajar.

Remmelink, Jan. 2003. Hukum Pidana. Jakarta: PT Gramedia Pustaka Utama.

Soemitro, Ronny Hanitijo. 1985. Metodologi Penelitian Hukum. Jakarta Timur: Ghalia Indonesia

Ujan, Andrea Ata. 2009. Filsafat Hukum: Membangun Hukum, Membela Keadilan. Yogyakarta: Kanisius

Kahan, Dan M. 1999. "The Secret Ambition Of Deterrence." Harvard Law Review

\section{Jurnal:}

Weinberger, Linda E. at.al. 2005. "The Impact of Surgical Castration on Sexual Recidivism Risk Among Sexually Violent Predatory Offenders". The Journal of the American Academy of Psychiatry and the Law, Volume 33, Number 1, 2005

Trendafilova, Aleksandra Deanoska and Andrej Bozhinovski. 2015. "Chemical Castration -The New Security Measure in the Macedonian Criminal Legislation". International Journal of Research in Applied, Natural and Social Sciences (IMPACT: IJRANSS), Vol. 3, Issue 10, Oct 2015 
Keesling, Lisa. 1999. "Practicing Medicine Without a License: Legislative Attempts to Mandate Chemical Castration For Repeat Sex Offenders". The John Marshall Law Review

\section{Makalah Seminar dan Disertasi:}

Stojanovski, Voislav. 2010. "Surgical Castration of Sex Offenders and its Legality: The Case of the Czech Republic". PrF D-TPV4 Theoretical Legal Sciences. Czech Republic: Doctoral Degree Program, Department of Criminal Law VI, Universitas Masarykiana Brunensis

Wilson, Debra. 2007. "The Legal Implications of Chemical Castration of Sex Offenders in Criminal Law", Paper presented at 62nd Annual Australasian Law Teachers Association (ALTA) Conference on Law and Public Policy: Taming the Unruly Horse? University of Western Australia, Perth, 23rd 26th, September 2007.

\section{Internet:}

http://www.republika.co.id, diakses tanggal 15 Juni 2016

http://nasional.republika.co.id, diakses tanggal 21 Juni 2016

http://www.beritasatu.com, diakses tanggal 21 Juni 2016 